\title{
Mycorrhiza and Common Mycorrhizal Network Regulate the Production of Signal Substances in Trifoliate Orange (Poncirus trifoliata)
}

\author{
Yi-Can ZHANG ${ }^{1,2}$, Chun-Yan LIU ${ }^{1,2 *}$, Qiang-Sheng WU ${ }^{1,2,3 * *}$ \\ ${ }^{1}$ Yangtze University, College of Horticulture and Gardening, Jingzhou, Hubei 434025, \\ China; 18871646639@163.com; chunyanliu_2009@126.com ("*joint first author);wuqiangsh@163.com (**orrespondingauthor) \\ ${ }^{2}$ Yangtze University, Institute of Root Biology, Jingzhou, Hubei 434025, \\ China;18871646639@163.com; chunyanliu_2009@126.com;wuqiangsh@163.com \\ ${ }^{3}$ University of Hradec Kralove, Department of Chemistry, Faculty of Science, Hradec Kralove, 50003, \\ Czech Republic;wuqiangsh@163.com
}

\begin{abstract}
Common mycorrhizal networks (CMNs) connecting two or more neighbouring plants are confirmed to transfer signals, whereas little information about CMNs effects on the signal substances production is known. In this study, a two-chambered rootbox separated by $37 \mu \mathrm{m}$ nylon mesh was used to establish donor and receptor chambers. Two chambers both were planted with trifoliate orange (Poncirus trifoliata) and then only donor chamber inoculated with Diversispora versiformis, Paraglomus occultum and Rhizoglomus intraradices. The roots of the donor and receptor plants both were mycorrhizated suggesting that CMNs were established between donor and receptor seedlings. Moreover, the AMF association dramatically increased plant height, stem diameter, leaf numbers, and shoot and root biomass in both the donor and receptor seedlings. The AMF inoculation in the donor plants and the subsequent mycorrhizal colonization by CMNs in the receptor plants significantly increased root calmodulin ( $\mathrm{CaM}$ ) and salicylic acid (SA) concentrations, while considerably decreased root nitric oxide (NO) and jasmonic acid (JA) concentrations. This was accompanied by down-regulated expression of three JA synthetic genes (PtLOX, PtAOS and PtAOC), regardless of donor and receptor seedlings. These results thus suggest that CMNs between trifoliate orange seedlings manifestly promote plant growth and affect the production of signal substances.
\end{abstract}

Keywords: calmodulin, jasmonic acid, nitric oxide, salicylic acid

\section{Introduction}

Arbuscular mycorrhizal fungi (AMF), a kind of beneficial soil microorganism, colonize roots of $\sim 80 \%$ of terrestrial plants and further form arbuscular mycorrhiza (AM) (Parniske, 2008). The host plant provides photosynthates to maintain AM formation and development, in addition to abundant external hyphae in soils (Leake et al., 2004). On the other hand, the external hyphae of AMs capture more water and nutrients from the soil and supply them to the host (Smith and Smith, 2011). The developed mycorrhizal external hyphae can colonize and further connect neighbouring plants of same or different species to form common mycorrhizal networks (CMNs) (Barto et al., 2012). AMF inoculation only impacts a narrow area which can be enlarged by mycorrhizal hyphal amalgamation (Giovannetti et al., 2004) and CMNs formation. Earlier works suggested that the CMN could develop between plants that are 12-20 cm apart (Song et al., 2010; Barto et al., 2011; Babikova et al., 2013).
CMNs benefit hosts in many ways, for instance improving seedling establishment and influencing plant and microorganism community composition (Van Der Heijden, 2004; Van Der Heijden and Horton, 2009). Zhang et al. (2014) demonstrated that the CMN with Diversispora spurca was established between trifoliate orange and white clover and improved growth of the non-inoculated plant (receiver plant). Furthermore, CMNs can be considered as conduits for the interplant nutrient and signal transduction ( $\mathrm{He}$ et al., 2003; Johnson and Gibert, 2015). Song et al. (2014) established CMNs with Funneliformis mosseae between herbivoreattacked and healthy tomato plants and found that CMNs transferred the jasmonic acid (JA) signaling to active defensive enzymes in receptor seedlings. CMNs regulate different physiological processes by transferring signal substrates to adapt to different stresses (Barto et al., 2011).

Apart from the JA, there are many other signal substances performing the regulation function, such as nitric oxide (NO), calmodulin (CaM), and salicylic acid (SA). As a signal molecule, NO activates protective enzymes in response to 
44

biotic and abiotic stresses (Besson-Bard et al., 2009). CaM as the second messenger always responds to various stimulations and also regulates massive cellular functions (Berridge et al., 2000). The SA and JA-dependence signaling pathways play a crucial role in plant defense reactions (Yang et al., 2015), and the subject has gained more attention in the recent past. Allene oxide synthase $(A O S)$, 13-lipoxygenase $(L O X)$, and allene oxide cyclase $(A O C)$ are key enzymes in JA biosynthesis pathway, the relative genes expression level which significantly influences JA concentration (Kombrink, 2012). Nevertheless, the effect of CMNs on signal substrates in trifoliate orange [Poncirus trifoliata (L.) Raf.] seedlings is little known.

In this work, a two-chambered rootbox was used to establish CMNs, and four signal substrates including NO, $\mathrm{CaM}, \mathrm{SA}$, and JA and the relevant JA synthetic genes expression were evaluated to clarify this mycorrhizal and CMN effect.

\section{Materials and Methods}

\section{Experimentaldesign}

A complete and random design was used in the experiment, with the AMF treatments taken as a single factor. Four AMF treatments were tested separately: Diversispora versiformis, Paraglomus occultum, Rbizoglomus intraradices and the nonAMF control. Each treatment had four replicates, totaling to 16 rootboxes.

\section{Mycorrbizal inoculum}

Diversispora versiformis (P. Karst.) Oehl, G.A. Silva \& Sieverd, Paraglomus occultum (Walker) Morton \& Redecker, and Rhizophagus intraradices (N.C. Schenck \& G.S. Sm.) C. Walker \& A. Schüßler were used here. The inoculum of these AMF species was provided by the Bank of Glomeromycota in China. Mycorrhizal inocula were propagated with both identified fungal spores and white clover (Trifolium repens) for 16 weeks in pots. The inoculums consisted of sands, spores and infected root segments.

At plant transplanting stage, approx. 1500 spores of each AM fungus were inoculated into the donor chamber of the rootbox, and the receptor chamber of the rootbox received the same amount of autoclaved inoculant plus $2 \mathrm{~mL}$ of mycorrhizal inoculum $(25 \mu \mathrm{m}$ filter $)$ to minimize differences in other microbial communities.

\section{Plant materials and culture}

Seeds of trifoliate orange were sterilized with $70 \%$ of ethyl alcohol solution and germinated in autoclaved $\left(0.1 \mathrm{MPa}, 121^{\circ} \mathrm{C}, 1\right.$ h) sands at $25^{\circ} \mathrm{C}$. After 30 days, three-leaf-old seedlings without mycorrhization were transplanted into a rootbox (Fig. 1). The twochambered rootbox was made of plexiglasses, with length, width and height of 10,8 and $18 \mathrm{~cm}$, respectively. The rootbox was divided into two equal chambers using two layers of $37-\mu \mathrm{m}$ nylon mesh, and an air gap of $1 \mathrm{~cm}$ width was created to avoid additional diffusion between the chambers. The 37- $\mu \mathrm{m}$ nylon mesh could allow mycorrhizal hyphae, other than roots, to move from one chamber into the other. One chamber of the rootbox was inoculated with AMF, hereby defined as root + hyphae chamber (donor). The hyphae of root + hyphae chamber went into the other chamber, forming root-free hyphae chamber (receptor). Each chamber was planted with two non-mycorrhization seedlings with three leaf and supplied with a $1.4 \mathrm{~kg}$ autoclaved growth substrate (soil: vermiculite $=5: 1$, volume $/$ volume).

The seedlings were grown in a glass house at the Yangtze University campus for 16 weeks. The temperature was $25 / 19^{\circ} \mathrm{C}$ day/night with $85 \%$ average relative humidity and the photo flux density varied from 721 to $967 \mu \mathrm{mol}^{-1} \mathrm{~m}^{-2} \mathrm{~s}^{-1}$.

\section{Variable determinations}

Before harvesting, plant height, stem diameter and the number of leafs per plant were recorded. Each seedling was divided into shoot and root, and the biomass was weighed.

Approx. five root segments per seedling with $1-2 \mathrm{~cm}$ long were collected and stained by $0.05 \%$ trypan blue solution in lacto gycerol, as described by Phillips and Hayman (1970). A total of 40 root segments in each treatment were used to calculate AMF colonization. The AMF colonization in roots was expressed as the percentage of AMF-colonized root length versus total observed root length. The soil hyphal length was determined using the protocol of Bethlenfalvay and Ames (1987). The hyphal length of nylon mesh was assayed by Zou et al. (2015) in $0.05 \%$ trypan blue solution.

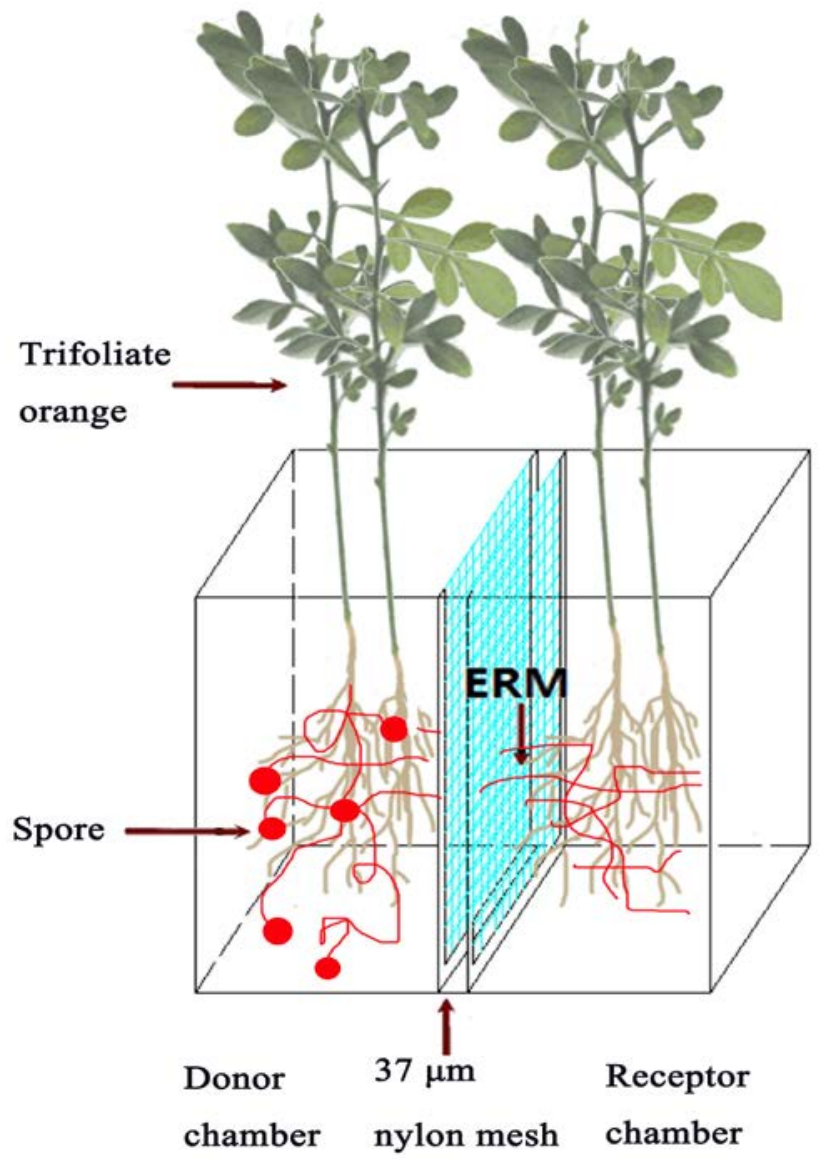

Fig. 1. The schematic diagram of the two-chambered rootbox. The rootbox was divided into two equal chambers by $37-\mu \mathrm{m}$ nylon mesh and two trifoliate orange seedlings were planted in donor and receptor chamber respectively. The donor chamber was inoculated with AMF, forming root + hyphae chamber. The hyphae, other than roots, forming in donor chamber passed through the nylon mesh into receptor chamber, and hence the receptor chamber was free root + hyphae chamber. ERM represented extraradical mycelia of mycorrhizal fungi 
Root samples were homogenized with phosphate buffer $(\mathrm{pH}$ 7.0) for extraction of $\mathrm{NO}, \mathrm{SA}$ and $\mathrm{JA}$, and with $0.6 \% \mathrm{NaCl}$ solution for $\mathrm{CaM}$ extraction. The root $\mathrm{NO}$ concentration was determined according to the nitric acid reductase method with $\mathrm{NO}$ kits in ELISA in accordance with the user handbook (A012, Nanjing Jiancheng Bioengineering Institute, China). Root CaM, SA and JA concentrations were evaluated by double antibody sandwich-elisa kits in ELISA as per the user handbook (Shanghai Enzymelinked Biotechology Co., Ltd, China).

The root sample was ground by liquid nitrogen, and root total RNA was extracted using a EASY spin Plus plant RNA kit (RN 38, Aidlab Biotecnolohies CO. Ltd, China), following the manufacturer's instruction. Thereafter, the total RNA was reversely transcribed to cDNA using the PrimeScript ${ }^{\mathrm{TM}}$ RT reagent kit with gDNA eraser (PK02006, Takara Bio. Inc, Japan), as per the manufacturer's instruction. Quantification real-time PCR (qRT-PCR) amplifications were carried out on a CFX96 Real Time PCR Detection System (BIO-RAD, USA) under the following compositions: $3.5 \mu \mathrm{L}$ sterile water, $0.5 \mu \mathrm{L}$ cDNA, $5 \mu \mathrm{L}$ SYBR GREEN PCR Master Mix (Applied Biosystems, CA, USA), $0.5 \mu \mathrm{L}$ forward prime and $0.5 \mu \mathrm{L}$ reverse prime. These primers for selected genes (PtLOX, PtAOS, and PtAOC) were designed based on Citrus sinensis data and shown in Table 1. The relative fold change in gene expression was calculated following the $2^{-} \Delta \Delta^{\mathrm{Ct}}$ method (Kenneth and Schmittgen, 2001) in which the reference gene acted as the control. The measured transcripts were normalized to the relative expression value in non-AM plants. Three independent biological replicates and three technical replicates for each sample were examined.

\section{Statistical analysis}

Data (means $\pm \mathrm{SD}, n=4$ ) were processed using the one-way ANOVA (SAS, version 8.1), and the Duncan's multiple range test (DMRT) was used to compare the significance of the difference among treatments at $P<0.05$.

\section{Results}

\section{Mycorrbizalstatus}

As shown in Table 2 and Fig. 2, hyphae of nylon meshes and soils were observed in inoculated treatments, and the donor chamber had more hyphal length than receptor chamber except for the soil hyphae inoculated with $R$. intraradices in the soil. All the seedlings were colonized regardless of donor and receptor seedlings, indicating that hyphae of donor chamber passed through the nylon mesh into receptor chamber and that CMNs were established between trifoliate orange seedlings grown in the two-chambered rootbox. The root mycorrhizal colonization of donor seedlings varied from $31.8 \%$ to $66.4 \%$, and that of receptor seedlings was from $26.8 \%$ to $61.0 \%$ (Table 2 ). In addition, a relatively higher root AM colonization was observed in the donor than in the receptor plants under three AMF species condition. Three AMF species had different affinities with trifoliate orange and ranked as $R$. intraradices $>P$. occultum $>D$. versiformis in both donor and receptor chamber.

\section{Plant growthperformance}

AMF-seedlings grew better than non-AMF seedlings (Table 3). For donor plants, inoculation with $D$. versiformis, $P$. occultum and $R$. intraradices increased the plant height by $71.1 \%, 133.5 \%$, and $153.8 \%$, and the leaf number by $36.8 \%$, $63.2 \%$, and $68.4 \%$, respectively, as compared with the nonAMF treatment. Likewise, root colonization by CMNs with $D$. versiformis, $P$. occultum and $R$. intraradices notably increased plant height by $40.3 \%, 51.3 \%$, and $53.3 \%$, and leaf number by $35.3 \%$, $41.2 \%$, and $47.1 \%$, respectively, in receptor plants, as compared with the non-CMN-colonized treatment. In comparison with non-AMF seedlings, the AMF-treatment had thicker stem diameter expect for the receptor plant inoculated with $R$. intraradices. The AMF inoculation and

Table 1. The specific primers designed for real time quantitative PCR amplification

\begin{tabular}{lccc}
\hline \multicolumn{1}{c}{ Gene name } & Gene ID & Sequence (5’-3’)-forward & Sequence (5’-3’)-reverse \\
\hline Actin & $C s 1 g 05000$ & CCGACCGTATGAGCAAGGAAA & TTCCTGTGGACAATGGATGGA \\
$P t L O X$ & $C s 3 g 13930$ & GCATCCTTTATTGATCGGTTTC & GGCAGGCTCGCCATG \\
$P t A O S$ & $C s 3 g 24230$ & ATCAAACGGCGGCAAAGTG & GTATTCTAACGCTACGGGTGG \\
$P t A O C$ & $C s 6 g 18900$ & AGATCGTGGCAGTCCAGCTT & GCTAAAAGGGACAAGATCACCAA \\
\hline
\end{tabular}
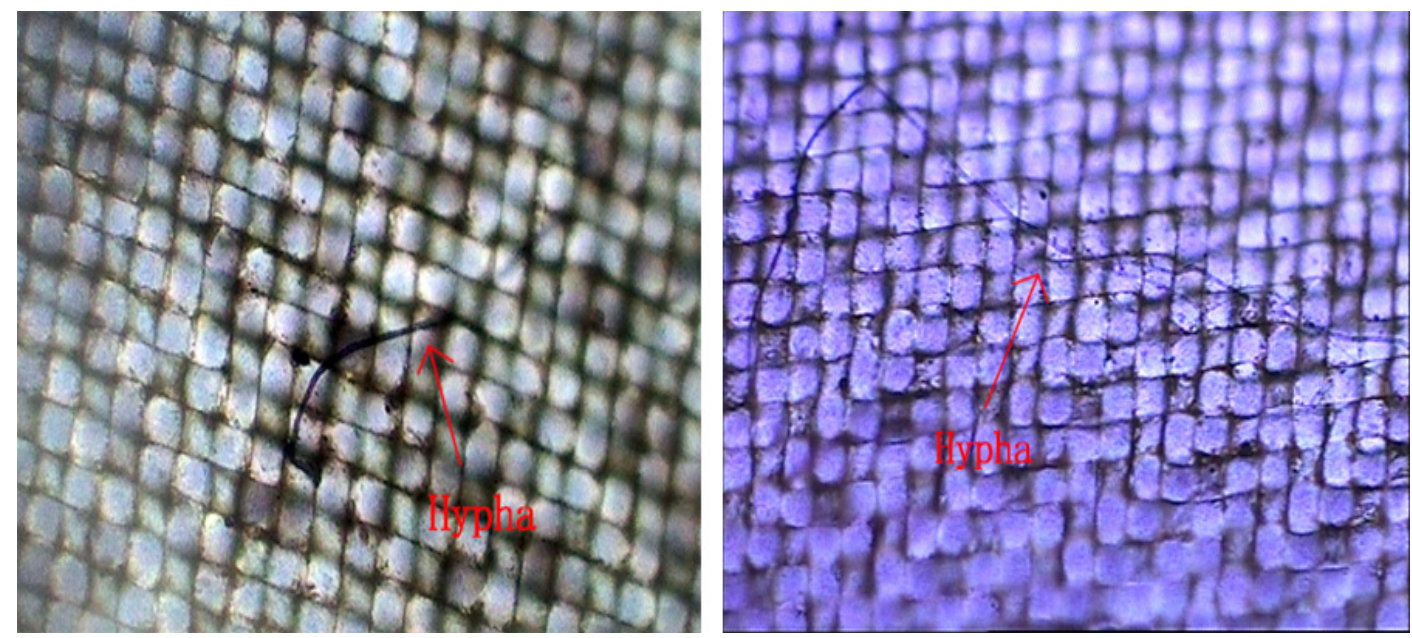

Fig. 2. The hypha on nylon mesh stained by trypan blue 
Table 2. The mycorrhizal status of Diversispora versiformis, Paraglomus occultum and Rhizogolmus intraradices colonized trifoliate orange seedlings grown in a two-chambered rootbox

\begin{tabular}{|c|c|c|c|c|c|c|}
\hline \multirow[t]{2}{*}{ Treatments } & \multicolumn{2}{|c|}{ Hyphal length of nylon mesh $\left(\mathrm{mm} / \mathrm{cm}^{2}\right)$} & \multicolumn{2}{|c|}{ Hyphal length of soil $(\mathrm{cm} / \mathrm{g})$} & \multicolumn{2}{|c|}{ Mycorrhizal colonization (\%) } \\
\hline & Donor & Receptor & Donor & Receptor & Donor & Receptor \\
\hline Non-AMF & $0 \pm 0 \mathrm{~d}$ & $0 \pm 0 \mathrm{~d}$ & $0 \pm 0 \mathrm{~d}$ & $0 \pm 0 \mathrm{~d}$ & $0 \pm 0 \mathrm{~d}$ & $0 \pm 0 \mathrm{~d}$ \\
\hline D. versiformis & $3.4 \pm 0.2 \mathrm{c}$ & $2.9 \pm 0.3 \mathrm{c}$ & $32.9 \pm 0.9 \mathrm{c}$ & $29.3 \pm 7.5 \mathrm{c}$ & $31.8 \pm 1.5 \mathrm{c}$ & $26.8 \pm 1.3 \mathrm{c}$ \\
\hline P. occultum & $5.0 \pm 0.3 b$ & $3.7 \pm 0.1 b$ & $54.2 \pm 5.1 \mathrm{~b}$ & $39.5 \pm 2.5 b$ & $38.5 \pm 1.4 b$ & $33.7 \pm 2.4 \mathrm{~b}$ \\
\hline R. intraradices & $5.7 \pm 0.6 \mathrm{a}$ & $4.6 \pm 0.3 \mathrm{a}$ & $70.79 \pm 3.4 \mathrm{a}$ & $77.6 \pm 4.1 \mathrm{a}$ & $66.4 \pm 2.9 \mathrm{a}$ & $61.0 \pm 3.8 \mathrm{a}$ \\
\hline
\end{tabular}

Note: Data (mean \pm SD, $n=4$ ) followed by the different letters in a column are the significantly difference $(P<0.05)$ according to DMRT

Table 3. Effects of Diversispora versiformis, Paraglomus occultum and Rhizogolmus intraradices inoculation on plant growth performance of trifoliate orange seedlings grown in a two-chambered rootbox

\begin{tabular}{|c|c|c|c|c|c|c|c|c|c|c|}
\hline \multirow[t]{2}{*}{ Treatments } & \multicolumn{2}{|c|}{$\begin{array}{l}\text { Plant height } \\
(\mathrm{cm})\end{array}$} & \multicolumn{2}{|c|}{$\begin{array}{l}\text { Stem diameter } \\
(\mathrm{mm})\end{array}$} & \multicolumn{2}{|c|}{$\begin{array}{c}\text { Leaf numbers } \\
\text { (\#/plant })\end{array}$} & \multicolumn{2}{|c|}{$\begin{array}{l}\text { Shoot biomass } \\
\text { (g FW/plant) }\end{array}$} & \multicolumn{2}{|c|}{$\begin{array}{l}\text { Root biomass } \\
\text { (g FW/plant) }\end{array}$} \\
\hline & Donor & Receptor & Donor & Receptor & Donor & Receptor & Donor & Receptor & Donor & Receptor \\
\hline Non-AMF & $15.88 \pm 0.77 \mathrm{~d}$ & $15.69 \pm 0.77 b$ & $2.62 \pm 0.13 c$ & $2.24 \pm 0.10 b$ & $19 \pm 1 \mathrm{c}$ & $17 \pm 1 b$ & $0.90 \pm 0.06 \mathrm{~d}$ & $0.83 \pm 0.03 c$ & $0.99 \pm 0.08 b$ & $0.99 \pm 0.04 b$ \\
\hline D. versiformis & $27.33 \pm 1.33 \mathrm{c}$ & $22.02 \pm 1.98 \mathrm{a}$ & $3.32 \pm 0.25 b$ & $3.32 \pm 0.20 \mathrm{a}$ & $26 \pm 1 b$ & $23 \pm 2 \mathrm{a}$ & $1.98 \pm 0.18 \mathrm{c}$ & $1.63 \pm 0.09 \mathrm{~b}$ & $0.99 \pm 0.08 \mathrm{~b}$ & $1.09 \pm 0.07 \mathrm{ab}$ \\
\hline P. occultum & $37.08 \pm 2.34 b$ & $23.74 \pm 1.66 a$ & $3.91 \pm 0.25 \mathrm{a}$ & $3.26 \pm 0.22 \mathrm{a}$ & $31 \pm 2 a$ & $24 \pm 2 a$ & $3.15 \pm 0.19 b$ & $1.72 \pm 0.15 \mathrm{ab}$ & $1.40 \pm 0.07 \mathrm{a}$ & $1.17 \pm 0.04 \mathrm{a}$ \\
\hline R. intraradices & $40.31 \pm 1.94 a$ & $24.05 \pm 2.13 \mathrm{a}$ & $3.02 \pm 0.15 b$ & $2.40 \pm 0.13 b$ & $32 \pm 1 a$ & $25 \pm 1 a$ & $3.51 \pm 0.28 \mathrm{a}$ & $1.80 \pm 0.10 \mathrm{a}$ & $1.43 \pm 0.11 \mathrm{a}$ & $1.04 \pm 0.01 b$ \\
\hline
\end{tabular}

Note: Data (mean $\pm \mathrm{SD}, n=4)$ followed by the different letters in a column are the significantly difference $(P<0.05)$ according to DMRT

CMN infection increased shoot and root biomass. Compared with the non-AMF treatment, $D$. versiformis, $P$. occultum and $R$. intraradices increased by $120 \%, 250 \%$, and $290 \%$ in shoot biomass and $0 \%, 41 \%$, and $72 \%$ in root biomass. The seedlings infected by CMN of $D$. versiformis, $P$. occultum and $R$. intraradices had $96 \%, 107 \%$, and $117 \%$ more in shoot biomass and $10 \%, 18 \%$, and $5 \%$ higher in root biomass in comparison with non-CMN seedlings.

\section{Root CaMconcentration}

$\mathrm{AMF}$ inoculation or subsequent $\mathrm{CMN}$ infection significantly elevated root $\mathrm{CaM}$ concentrations in comparison with non-AMF inoculation, regardless of the donor and receptor seedlings. Compared with non-AMF treatment, the root $\mathrm{CaM}$ concentrations were 9.1\%, 11.8\%, and $20.9 \%$ higher in donor seedlings, and $14.0 \%, 25.7 \%$, and $40.2 \%$ higher in receptor seedlings under inoculation with $D$. versiformis, $P$. occultum and $R$. intraradices conditions, respectively (Fig. 3).

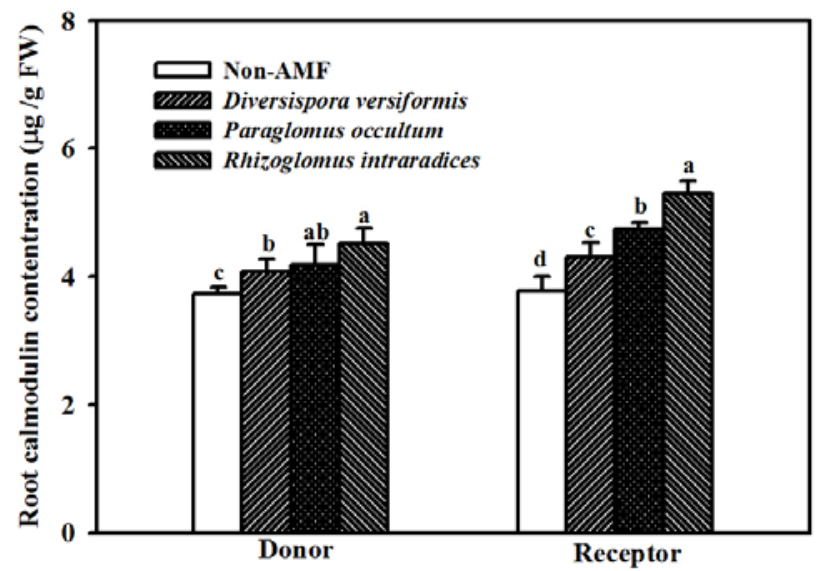

Fig. 3. Effects of Diversispora versiformis, Paraglomus occultum and Rhizogolmus intraradices inoculation on root calmodulin level of trifoliate orange seedlings grown in a two-chambered rootbox. Bars (means $\pm \mathrm{SD}, n=4$ ) bearing different letters are significantly different $(P<0.05)$ according to DMRT

\section{Root NO concentration}

Three AMF species all decreased root NO accumulation, but the restraining level was slightly different among treatments (Fig. 4). Compared with non-AMF treatment, the root NO concentrations decreased by $21.1 \%, 60.7 \%$, and $24.1 \%$ in donor plants and $18.3 \%, 25.4 \%$, and $48.0 \%$ in receptor plants inoculated with $D$. versiformis, $P$. occultum and $R$. intraradices, respectively.

\section{Root SA concentration}

In contrast with the non-mycorrhizal seedlings, the mycorrhizal trifoliate orange seedlings showed significantly higher root SA concentrations: $29.6 \%$ and $36.7 \%$ in donor and receptor seedlings when inoculated with $D$. versiformis, 9.9\% and $12.5 \%$ under mycorrhization with P. occultum, and $11.7 \%$ and $25.5 \%$ under mycorrhization with $R$. intraradices, respectively (Fig. 5).

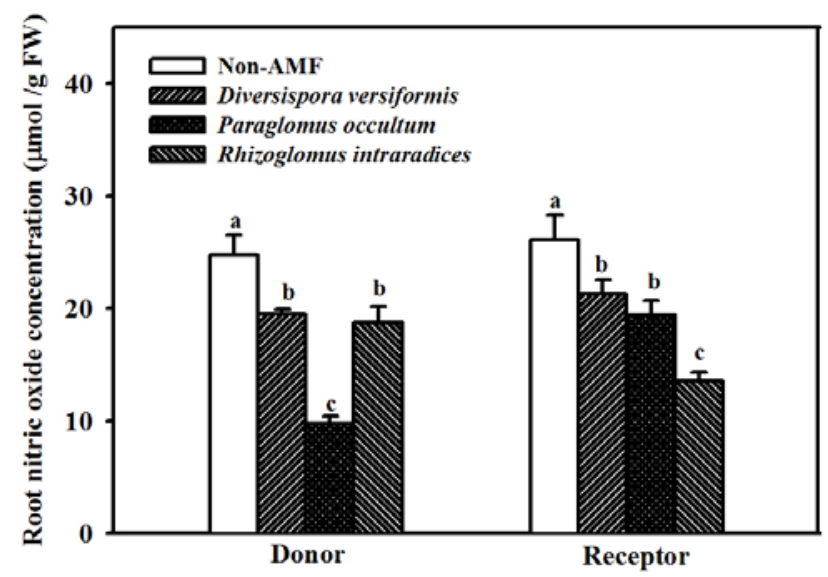

Fig. 4. Effects of Diversispora versiformis, Paraglomus occultum and Rhizogolmus intraradices, inoculation on root nitric oxide level of trifoliate orange seedlings grown in a two-chambered rootbox. Bars (means $\pm \mathrm{SD}, n=4$ ) bearing different letters are significantly different $(P<0.05)$ according to DMRT 


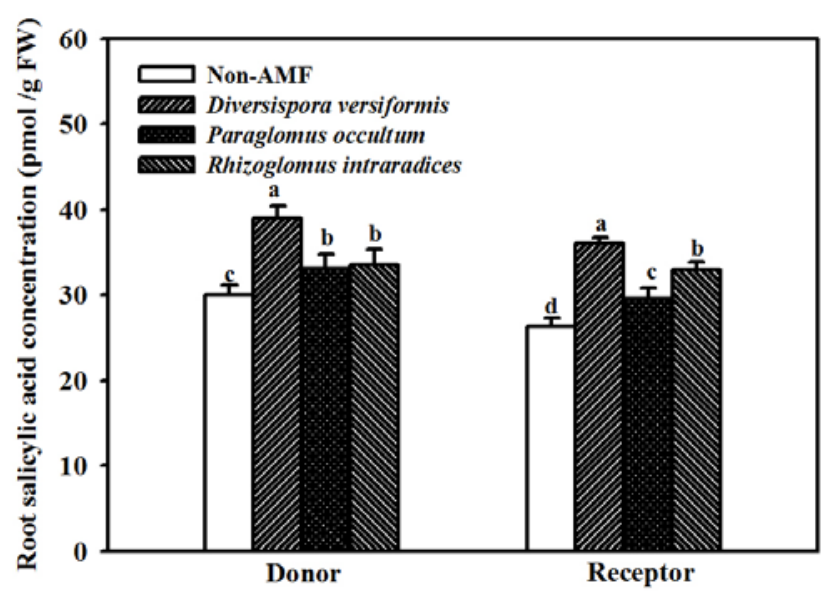

Fig. 5. Effects of Diversispora versiformis, Paraglomus occultum and Rhizogolmus intraradices inoculation on root salicylic acid level of trifoliate orange seedlings grown in a two-chambered rootbox. Bars (means $\pm \mathrm{SD}, n=4$ ) bearing different letters are significantly different $(P<0.05)$ according to DMRT

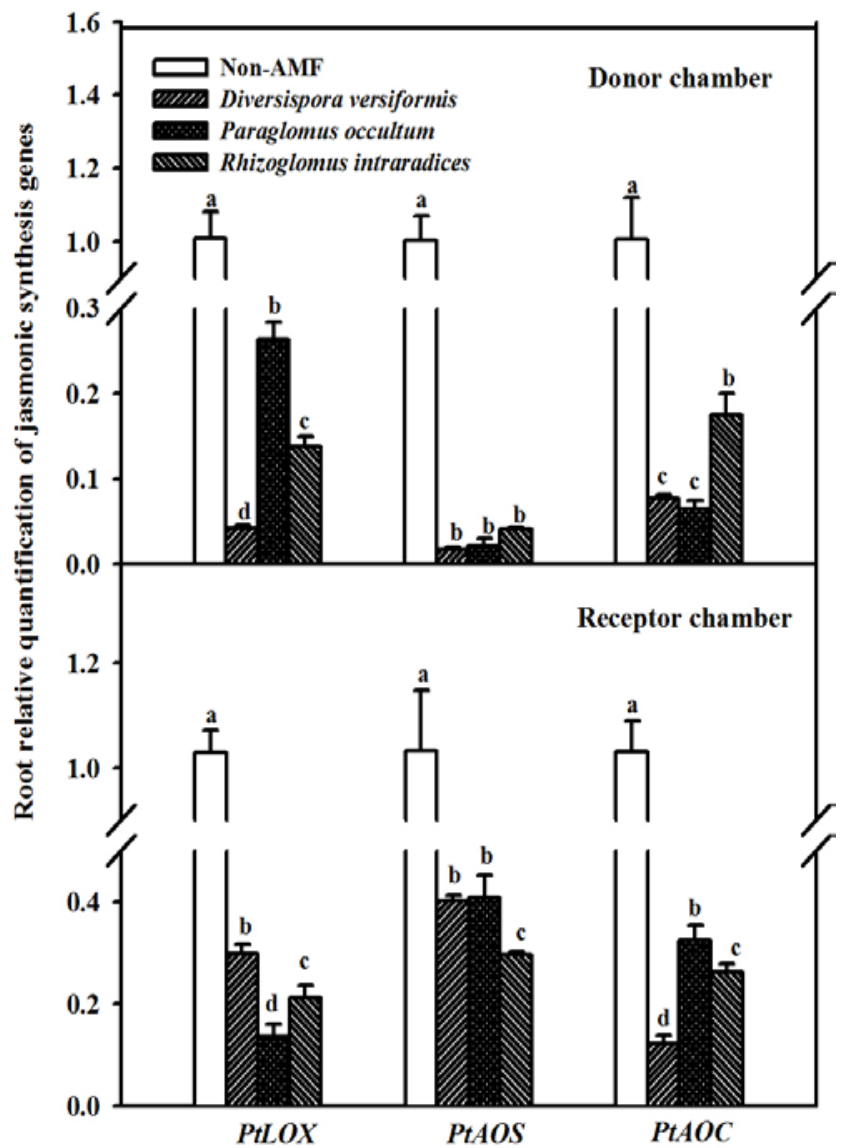

Fig. 7. Effects of Diversispora versiformis, Paraglomus occultum and Rhizogolmus intraradices inoculation on relative expression of root jasmonic acid synthetic genes of trifoliate orange seedlings grown in a two-chambered rootbox. The non-AMF treatment was acted as the control in which the gene expression level was 1 . Bars (means \pm $\mathrm{SD}, n=4)$ bearing different letters are significantly different $(P<$ 0.05 ) according to DMRT

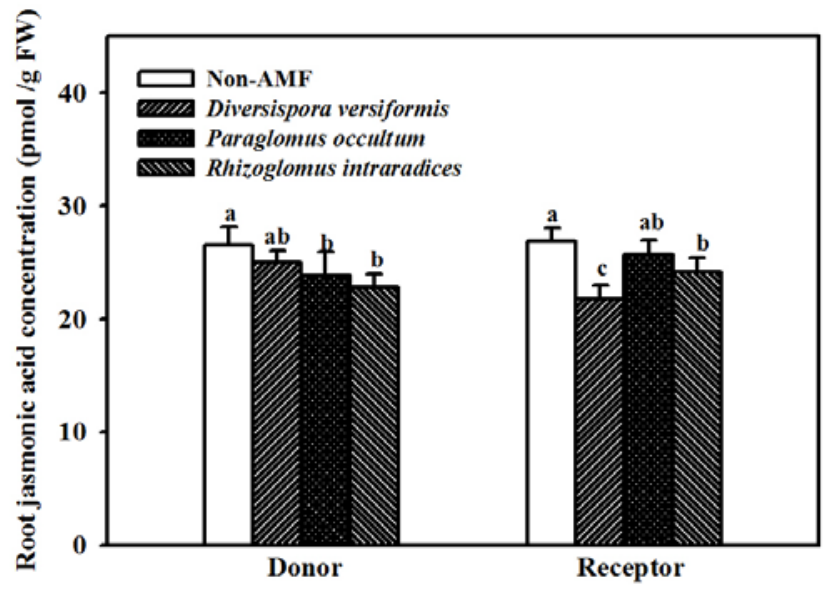

Fig. 6. Effects of Diversispora versiformis, Paraglomus occultum and Rhizogolmus intraradices inoculation on root jasmonic acid level of trifoliate orange seedlings grown in a two-chambered rootbox. Bars (means $\pm \mathrm{SD}, n=4$ ) bearing different letters are significantly different $(P<0.05)$ according to DMRT

\section{Root JA concentration}

Inoculation with $P$. occultum and $R$. intraradices decreased root JA concentrations by $10.3 \%$ and $14.2 \%$ in donor seedlings, respectively, whereas $D$. versiformis had no significant change in root JA concentration of donor seedlings, as compared with non-AMF treatment (Fig. 6). In receptor seedlings, CMNs with $D$. versiformis and $R$. intraradices reduced root JA concentrations respectively by $19.0 \%$ and $10.0 \%$, while $P$. occultum had no significant effects on root JA concentrations, as compared with the non-AMF inoculation.

\section{Relative expression of $\mathrm{A}$ A synthetic genes}

qRT-PCR analysis revealed that AMF inoculation significantly down-regulated the expression of three JA synthetic genes in donor and receptor roots (Fig. 7). In donor plants, in contrast with non-AMF inoculation, $D$. versiformis decreased the expression of PtLOX, PtAOS and PtAOC genes respectively by $96 \%, 98 \%$, and $92 \%$. On the other hand, the decrease under $P$. occultum was by $74 \%, 98 \%$, and $94 \%$; and $R$. intraradices was by $86 \%, 96 \%$, and $83 \%$. Similarly, the CMNinfected receptor seedlings had $71 \%, 61 \%$, and $88 \% ; 87 \%, 61 \%$, and $68 \%$; and $79 \%, 71 \%$, and $75 \%$ lower expression of (respectively) PtLOX, PtAOS, and PtAOC genes in roots, compared with non-CMN-infected controls.

\section{Discussion}

In the two-chambered rootbox, the CMNs were formed between donor chamber inoculated with mycorrhizal and noninoculation receptor chamber, and such treatments significantly stimulated growth performance in the donor and receptor seedlings. This is in agreement with earlier studies in trifoliate orange-white clover system (Zhang et al., 2014). Since the AM association was established earlier in seedlings of the donor chamber, the effect of mycorrhizal colonization was more profound in donor seedlings than in receptor seedlings. 
48

Meanwhile, three AMF species behaved differently as a result of the inoculation effect, possibly due to AMF specificity with the host plant (Van Der Heijden et al., 1998).

The complex of calcium $\left(\mathrm{Ca}^{2+}\right)$ and $\mathrm{CaM}$ acts as the signaling to regulate physiological metabolisms (Kim et al., 2009), which is employed by AMF to strengthen the signal transduction. Chabaud et al. (2011) indicated that exudates from AMF spores induced $\mathrm{Ca}^{2+}$ rapid increase and Gleason $e t$ al. (2006) further proved that $\mathrm{Ca}^{2+} / \mathrm{CaM}$ regulated calcium and calmodulin-dependent kinase (CCaMK) and induced specific gene transcription. Huang et al. (2014) reported that inoculation with $F$. mosseae increased $\mathrm{CaM}$ level and promoted the resistance to drought stress in trifoliate orange. In this work, inoculation with AMF activated root $\mathrm{CaM}$ level in donor seedlings, and subsequent $\mathrm{CMN}$ colonization also promoted root CaM increase in receptor seedlings. It was suggested that AMF inoculation and CMN colonization had similar effect on regulating the $\mathrm{Ca}^{2+} / \mathrm{CaM}$ signal pathway.

In our work, mycorrhizal colonization strongly decreased the root NO concentration, irrespective of AMF species and donor or receptor plants. Earlier studies proved that $\mathrm{NO}$ took part in the post-translational modification of protein involving stress, redox and signaling/regulating (Lindermayr et al., 2005). It may be speculated that more NO was used to modify proteins for performing various functions under AMF inoculation conditions. Concurrently, the receptor seedlings had the same tendency with donor seedlings, which meant that the $\mathrm{CMN}$-infected seedlings also employed more $\mathrm{NO}$ to mediate physiological functioning.

Earlier studies showed that both SA and JA could transfer the signal of wounding, pathogen, and herbivores attack to trigger the defense responses in plants (Malamy et al., 1990; Wasternack and Parthier, 1997; Sanders et al., 2000). After colonization, the biotrophic microorganisms including AMF trigger the system to acquire resistance, which is always accompanied with more SA accumulation (Dempsey et al., 2011). The SA signals exhibit a more durable and intense response to pathogen infection (Song et al., 2010). Other studies showed that inoculation with $F$. mosseae promoted the phenolic synthesis via SA signaling pathways and plant disease resistance was further enhanced (Zhang et al., 2013). In the present work, AM seedlings, regardless of donor and receptor, showed significantly higher root SA levels but lower root JA concentrations accompanied with the down-regulation of three JA synthetic genes (PtLOX, PtAOS, and PtAOC), compared with non-AMF treatment. Therefore, it is suggested that mycorrhizal seedlings connected by CMNs might have a relatively greater capacity to tolerate pathogen attack by increasing $S A$ concentration.

In general, SA inhibited JA biosynthesis and defense responses (Glazebrook, 2001; Robert-Seilaniantz et al., 2011) and the inhibiting effect always realized by transcription factors such as WRKY70, WRKY62, MPK4, MYC2, and NPR1 (Bari and Jones, 2009). The inhibition was also shown in this present work, with an increase of root SA but a decrease of root JA. SA accumulation was at the cost of JA synthesis depression, which was also confirmed by Spoel et al. (2003) and Laudert and Weiler (1998). In our work, the JA synthetic gene expression was more susceptible than JA level under mycorrhizal colonization conditions, regardless of donor and receptor seedlings. Isayenkov et al. (2005) also found that $A O C$ transcripts had more significant change than $A O C$ protein under mycorrhization condition. Perhaps there are nonknown factors that affect JA protein translation. Therefore, the mechanisms by which the synthesis related genes influence JA level in roots need to be further investigated.

\section{Conclusions}

The CMNs were established between trifoliate orange seedlings and played vital roles in growth promotion and production of signal substances. Inoculation with AMF increased root and shoot biomass in both donor and receptor seedlings. Meanwhile, the signal pathways were activated by inoculating with AMF. There were more root $\mathrm{CaM}$ and SA but less root NO and JA along with down-regulation of JA synthetic genes (PtLOX, PtAOS, and PtAOC) under mycorrhization.

\section{Acknowledgements}

This study was supported by the 'Plan in Scientific and Technological Innovation Team of Outstanding Young', Hubei Provincial Department of Education (T201604).

\section{References}

BabikovaZ, Gilbert L, Bruce TJA, Birkett M, CaulfieldJCC, Woodcock C, Pickett JA, Johnson D (2013). Underground signals carried through common mycelial network warn neighbouring plants of aphid attack. Ecology Letters 16:835-843.

Bari R, Jones JDG (2009). Role of plant hormones in plant defence responses. Plant Molecular Biology 69:473-488.

Barto EK, Hilker M, Müller F, Mohney BK, Weidenhamer JD, Rillig MC (2011). The fungal fast lane: common mycorrhizal network extend bioactive zones of alleochemicals in soil. PLOS ONE 6:e27195.

Barto EK, Weidenhamer JD, Cipollini D, Rillig MC (2012). Fungal superhighways: do common mycorrhizal networks enhance below ground communication? Trends in Plant Science 17:633-637.

Berridge MJ, Lipp P, Bootman MD (2000). The versatility and universality of calcium signaling. Nature Reviews Molecular Cell Biology 1:11-21.

Besson-Bard A, AstierJ, Rasual S, Wawer I, Dubreuil-Maurizi C,JeandrozS, Wendehenne D (2009). Current view of nitric oxide-responsive genes in plants. Plant Science 177:302-309.

Bethlenfalvay GJ, Ames RN (1987). Comparison of two methods for quantifying extraradical mycelium of vesicular-arbuscular mycorrhizal fungi. Soil Science Society of America Journal 51:834837.

Chabaud M, Genre A, Sieberer B, Faccio A, Fournier J, Novero M, Barker DG, Bonfante P (2011). Arbuscular mycorrhizal hyphopodia and germinated spore exudates trigger $\mathrm{Ca}^{2+}$ spiking in the legume and nonlegume rootepidermis. New Phytologist 189:347-355.

Dempsey DA, Vlot AC, Wildermuth MC, Klessig DF (2011). Salicylic acid biosynthesis and metabolism. Arabidopsis book 9:0156.

Giovannetti M, Sbrana C, Avio L, Strani P (2004). Patterns of belowground plant interconnections established by means of arbuscular mycorrhizal networks. New Phytologist 164:175-181.

Glazebrook J (2001). Genes controlling expression of defense responses in Arabidopsis-2001status. Current Opinion in Plant Biology 4:301-308. 
49

Gleason C, Chaudhuri S, Yang TB, Munoz A, Poovaiah BW, Oldroyd GED (2006). Nodulation independent of rhizobia induced by calciumactivated kinase lacking autoinhibition. Nature 441:1149-1152

He XH, Critchley C, Bledsoe C (2003). Nitrogen transfer within and between plants through common mycorrhizal networks (CMNs). Critical Reviewersin Plant Science 22:531-567.

Huang YM, Srivastava AK, Zou YN, Ni QD, Han Y, Wu QS (2014). Mycorrhizal-induced calmodulin mediated changes in antioxidant enzymes and growth response of drought-stresses trifoliate orange. Frontiers in Microbiology 5:682.

Isayenkov S, Mrosk C, Stenzel I, Strack D, Hause B (2005). Suppression of allene oxide cyclase in hairy roots of Medicago truncatula reduces jasmonate levels and the degree of mycorrhization with Glomus intraradices.Plant Physiology 139:1401-1410.

Johnson D, Gibert L (2015). Interplant signaling through hyphal networks. New Phytologist 205:1148-1153.

Kenneth JL, Schmittgen TD (2001). Analysis of relative gene expression data using real-time quantitative $\mathrm{PCR}$ and $2^{-\Delta \mathrm{AC}}$ method. Methods 25:402408.

Kim MC, Chung WS, Yun DJ, Cho MJ (2009). Calcium and calmodulin mediated regulation of gene expression in plants. Molecular Plant 2:1321.

Kombrink E (2012). Chemical and genetic exploration of jasmonate biosynthesis and signaling paths. Planta 236:1351-1366.

Laudert D, Weiler EW (1998). Allene oxide synthase: a major control point in Arabidopsis thaliana octadecanoid signalling. The Plant Journal 15:675-684.

Leake J, Johnson D, Donnelly D, Muckle G, Boddy L, Read D (2004). Networks of power and influence: the role of mycorrhizal mycelium in controlling plant communities and agroecosystem function. Canadian Journal of Botany 82:1016-1045.

Lindermayr C, Saalbach G, Durner J (2005). Proteomic identification of Snitrosylated proteins in Arabidopsis. Plant Physiology 137:921-930.

Malamy J, Carr JP, Klessig DF, Raskin I (1990). Salicylic acid: A likely endogenous signal in the resistance response of tobacco to viral infection. Science 250:1002-1004.

Parniske M (2008). Arbuscular mycorrhiza: the mother of plant root endosymbioses. Nature Reviews Microbiology 6:763-775.

Phillips JM, Hayman DS (1970). Improved procedures for clearing roots and staining parasitic and vesicular-arbuscular mycorrhizal fungi for rapid assessment of infection. Transactions of the British Mycological Society 55:158-161.

Robert-Seilaniantz A, Grant M, Jones JDG (2011). Hormone crosstalk in plant disease and defense more than just jasmonate-salicylate antagonism. Annual Review of Phytopathology 49:317-343.
Sanders PM, Lee PY, Biesgen C, BooneJD, Beals TP, WeilerEW, Goldberg RB (2000). The Arabidopsis DELAYED DEHISCENCEI gene encode an enzyme in the jasmonic acid synthesis pathway. The Plant Cell 12:1041-1061.

Smith SE, Smith FA (2011). Roles of arbuscular mycorrhizas in plant nutrition and growth: New paradigms form cellular to ecosystem scales. Annual Review of Plant Biology 62:227-250.

Song YY, Ye M, Li CY, He XH, Zhu-Salaman KA, Wang RL, Su YJ, Luo SM, Zeng RS (2014). Hijacking common mycorrhizal networks for herbivore-induced defense signal transfer between tomato plants. Scientific Reports 4:3915.

Song YY, Zeng RS, Xu JF, Shen X, Yihdego WG (2010). Interplant communication of tomato plants through underground commom mycorrhizal networks. PLOS ONE 5:e13324.

Spoel SH, Koornneef A, Claessens SMC, Korzelius J, Van Pelt JA, Mueller MJ, Buchala AJ, Metraux JP, Brown R, Kazan K, Van Loon LC, Dong $\mathrm{X}$, Pieterse CM (2003). NPRI modulates cross-talk between salicylateand jasmonate-dependent defense pathways through a novel function in the cytosol. The Plant Cell 15:760-770.

Van Der Heijden MGA, Klironomos JN, Ursic M, Moutogis P (1998). Mycorrhizal fungi diversity determines plant biodiversity, ecosystem variability and productivity. Nature 396:69-72.

Van Der Heijden MGA (2004). Arbuscular mocorrhizal fungi as support systems for seedling establishment in grassland. Ecology Letters 7:293303.

Vav Der Heijden MGA, Horton TR (2009). Socialism in soil? The importance of mycorrhizal fungi networks for facilitation in natural ecosystems. Journal of Ecology 97:1139-1150.

Wasternack C, Parthier B (1997).Jasmonate-signalled plant gene expression. Trends in Plant Science 2:302-307.

Yang YX, Ahammed GJ, Wu C, Fan SY, Zhou YH (2015). Crosstalk among jasmonate, salicylate and ethylene signaling pathways in plant disease and immune response. Current Protein and Peptide Science 16:450-461.

Zhang RQ, Zhu HH, Zhao HQ, Yao Q (2013). Arbuscular mycorrhizal fungi inoculation increases phenolic synthesis in clover roots via hydrogen peroxide salicylic acid and nitric oxide signaling pathways. Journal of Plant Physiology 170:7479.

Zhang ZZ, Lou YG, Deng DJ, Rahman MM, Wu QS (2014). Effect of common mycorrhizal network on plant carbohydrates and soil properties in trifoliate orange-white clover association. PLOS ONE 10: e0142371.

Zou YN, Srivastava AK, Ni QD, Wu QS (2015).Disruption of mycorrhizal extraradical mycelium and changes in leaf water status and soil aggregate stability in rootbox-grown trifoliate orange. Frontiers in Microbiology 6:203. 